\title{
Definition of a data model that includes the instructional design to describe the elements involved in the design of virtual courses
}

Betsy Mary Estrada Perea / bmestrada@correo.iue.edu.co Institución Universitaria de Envigado, Colombia

ABSTRACT Conventional software engineering methodologies have strategies for analysis and design of educational software applications, but they have evolved in relation to the phase of the instructional design. In this article, from the review of some models of instructional design and the identification of gaps in two proposed models for the design of virtual courses, a data model is proposed to describe the elements involved in the design of virtual courses and illustrate the relationships between such elements. In preparing this model, we take into account the activities of some models of instructional design. The construction of this data model is a contribution to formalize the design of virtual courses.

KEYWORDS Data model; instructional design; virtual course.

Definición de un modelo de datos que incluye el diseño instruccional para describir los elementos que intervienen en el diseño de cursos virtuales

RESUMEN Las metodologías convencionales de ingeniería de software tienen estrategias para el análisis y diseño de aplicaciones de software educativo, pero poco han evolucionado en lo relacionado con la fase del diseño instruccional. En este artículo, a partir de la revisión de algunos modelos de diseño instruccional y la identificación de vacios en dos modelos propuestos para el diseño de cursos virtuales, se propone un modelo de datos para describir los elementos que intervienen en el diseño de cursos virtuales e ilustrar las relaciones entre tales elementos. Para la elaboración este modelo se tienen en cuenta las actividades de algunos modelos de diseño instruccional. La construcción de este modelo de datos es un aporte a la formalización del diseño de cursos virtuales.

PALABRAS CLAVE Modelo de datos; diseño instruccional; curso virtual.
Definição de um modelo de dados que inclui o design instrucional para descrever os elementos envolvidos na concepção de cursos virtuais

RESUMO As metodologias convencionais de engenharia de software têm estratégias para a análise e desenho de aplicações de software educacionais, mas têm evoluído pouco em relação à fase do design instrucional. Neste artigo, a partir da revisão de alguns modelos de design instrucional e a identificação de lacunas em dois modelos propostos para a concepção de cursos virtuais, é proposto um modelo de dados para descrever os elementos envolvidos na concepção de cursos virtuais e ilustrar os relacionamentos entre tais elementos. A elaboração deste modelo leva em conta as atividades de alguns modelos de design instrucional. A construção deste modelo de dados é uma contribuição para a formalização da concepção de cursos virtuais.

PALAVRAS-CHAVE Modelo de dados; design instrucional; curso virtual. 


\section{Introduction}

A virtual course is a kind of educational software where students interact with information and activities designed to develop skills and competencies and acquire knowledge, based on learning objectives (Ministerio de Educación Nacional, 2011). The design of a virtual course includes the planning, preparation and design of resources and situations needed to carry out learning; the instructional design phase of the development process is the virtual course that provides guidelines for it.

However, many of the data models proposed as part of the design of a virtual course leave out some of the steps or phases of instructional design. Among the shortcomings of such designs are: the lack or incompleteness in the definition of the student entity, which does not allow the registering of their behaviors and characteristics related to the learning process, as well as the lack of attributes to save the instructional goal or learning goals of each unit of content for a virtual course.

Therefore, in this article the development of a data model that considers the instructional design is proposed, describing the elements involved in the design of virtual courses and showing the relationships between these elements. The construction of this data model is proposed as a contribution to formalize the design of virtual courses.

This article has the following structure: Section II presents the methodology; in Sections III, IV and V, respectively, virtual courses are defined and the activities or steps of instructional design models are described; some models proposed for the design of virtual courses are analyzed; and the proposed model is presented; in section VI the conclusions and future work are presented.

\section{Methodology}

For the results presented in this article the following steps were taken:

- Study of different instructional models and the phases or activities that compose them. A literature review was made of information related to different instructional models, so that each of the phases or activities that are carried out in order to facilitate the teachinglearning process were identified.

- Analysis of different data models for the design of virtual courses and educational websites within the instructional models presented. Different data models created in the design phase of virtual courses and

\section{Introducción}

Un curso virtual es un tipo de software educativo donde los estudiantes interactúan con información y actividades con el propósito de desarrollar capacidades y competencias y adquirir conocimientos, atendiendo a unos objetivos de aprendizaje (Ministerio de Educación Nacional, 2011). El diseño de un curso virtual incluye la planeación, la preparación y el diseño de los recursos y las situaciones necesarias para que se lleve a cabo el aprendizaje; la fase del diseño instruccional del proceso de desarrollo del curso virtual es la que proporciona las pautas para ello.

Sin embargo, muchos de los modelos de datos propuestos como parte del diseño de un curso virtual dejan de lado algunos de los pasos o fases del diseño instruccional. Entre las carencias de tales diseños están: la falta o incompletitud en la definición de la entidad estudiante, que no permite registrar sus conductas y características relacionadas con el proceso de aprendizaje, la inexistencia de atributos para guardar la meta instruccional o los objetivos de aprendizaje de cada unidad de contenido para un curso virtual.

Por lo anterior, en este artículo se propone la elaboración de un modelo de datos que considera el diseño instruccional, describe los elementos que intervienen en el diseño de cursos virtuales y muestra las relaciones entre tales elementos. La construcción de este modelo de datos se plantea como un aporte a la formalización del diseño de cursos virtuales.

Este artículo tiene la siguiente estructura: en la sección II se presenta la metodología; en las secciones III, IV y V, respectivamente, se definen los cursos virtuales y se describen las actividades o pasos de algunos modelos de diseño instruccional; se analizan algunos modelos propuestos para el diseño de cursos virtuales; y se expone el modelo propuesto; en la sección VI se presentan las conclusiones y el trabajo futuro.

\section{Metodología}

Para obtener los resultados presentados en este artículo se siguieron estos pasos:

- Estudio de diferentes modelos instruccionales y de las fases o actividades que los componen. Se revisó en la literatura información relacionada con diferentes modelos instruccionales, para cada uno de ellos se identificaron las fases o actividades que se llevan a cabo con el fin de facilitar el proceso de enseñanza-aprendizaje.

- Análisis de diferentes modelos de datos para el diseño de cursos virtuales y sitios web educativos en el marco de los modelos instruccionales presentados. Se seleccionaron diferentes modelos de datos creados en la fase de diseño de cursos virtuales y otras aplicaciones de software educativas, y se identificó a las entidades relevantes; se evidencia la ausencia de otras entidades necesarias para poder desarrollar la instrucción por medio del curso virtual o de la aplicación de software 
educativo según los modelos de instrucción propuestos.

- Diseño de un modelo de datos que incluye lineamientos del diseño instruccional en el modelado de curso virtual. En la elaboración del modelo de datos propuesto en este artículo como estrategia para garantizar el seguimiento de un modelo instruccional. Se empleó la herramienta Toad Data Modeler. El modelo incluye las entidades relevantes, sus atributos y las relaciones que permitirían llevar a cabo las actividades y fases identificadas para cada modelo instruccional estudiado. En el modelo se especifica información a nivel físico, tal como el tipo de dato de los atributos, la definición de claves primarias y foráneas, además de las restricciones de datos no nulos.

\section{Modelos instruccionales y sus fases}

Los cursos virtuales son un tipo de aplicación de software educativo y como tal son programas computacionales que buscan facilitar el proceso de aprendizaje (Vidal, Gómez, \& Ruiz, 2010). Según Miller y Miller (2000), en el diseño de un curso virtual se deben tener en cuenta: la orientación teórica - enfoque pedagógico-, las metas y objetivos de aprendizaje, los contenidos, las características del estudiante y la capacidad tecnológica -recursos tecnológicos tales como redes de datos, bases de datos, herramientas para la comunicación, interacción y colaboración, servidores, entre otros-.

Diseñar un curso virtual requiere mucho más que la construcción de un programa de computador, página o sitio web con materiales digitales enlazados. La enseñanza mediante cursos virtuales u otro tipo de software educativo requiere de un diseño instruccional capaz de crear un ambiente que facilite el aprendizaje, teniendo en cuenta que la interacción entre el docente y el estudiante no siempre se da en forma directa. El diseño instruccional se centra en la relación entre el entendimiento y el desarrollo de un proceso, y pone a disposición métodos de enseñanza con la finalidad de generar cambios en las habilidades y conocimientos de los estudiantes (Reigeluth, 1983). A continuación se describen brevemente los elementos de tres modelos de diseño instruccional.

El modelo de Dick, Carey y Carey (2005) contempla los siguientes pasos (Saettler, 2004):

- identificación de la meta instruccional;

- análisis de los estudiantes y del contexto, que consiste en conocer de entrada las conductas y características de los estudiantes;

- planteamiento de objetivos, los que se definen para cada unidad del contenido;

- desarrollo de instrumentos de evaluación;

- construcción de la estrategia instruccional;

- desarrollo y selección de los materiales de instrucción; other educational software applications were selected, and the relevant entities were identified; the absence was determined of other entities needed to develop the instruction through the virtual course or educational software application according to the model instruction proposed.

- Designing a data model that includes instructional design guidelines in modeling a virtual course. The development of the data model is proposed as a strategy to ensure the monitoring of an instructional model in this article. The Toad Data Modeler tool was used. The model includes the relevant entities, their attributes, and relationships that make it possible to carry out the activities and the phases identified for each instructional model studied. In the model the physical level information is specified, as well as the data type of the attributes, the definition of primary and foreign keys, in addition to the restrictions of non-zero data.

\section{Instructional models and their phases}

Virtual courses are a type of educational software application and as such are computer programs that seek to facilitate the learning process (Vidal, Gomez, \& Ruiz, 2010). According to Miller and Miller (2000), in the design of a virtual course it is necessary to take into account: the theoretical orientation - pedagogical approach-, goals and learning objectives, content, student characteristics and technological capacity -technological resources such as data networks, databases, tools for communication, interaction and collaboration, and servers, among others.

Designing a virtual course requires much more than building a computer program, page or website with digital materials linked. Education through online courses or other educational software requires an instructional design that is able to create an environment that facilitates learning, taking into account that the interaction between teacher and student is not always given directly. The instructional design focuses on the relationship between the understanding and development of a process, and provides teaching methods in order to generate changes in the skills and knowledge of students (Reigeluth, 1983). The following briefly describes the elements of three models of instructional design.

The Dick, Carey and Carey model (2005) includes the following steps (Saettler, 2004):

- identification of the instructional goal; 
- analysis of students and context, which is in order to know the input behaviors and characteristics of students;

- setting objectives, which are defined for each unit of content;

- development of assessment tools;

- construction of the instructional strategy;

- development and selection of instructional materials;

- design and development of formative assessment;

- design and development of the summative evaluation, which refers to the value of instruction; and

- review of instruction.

The EPISD model (Interservice Procedures for Instructional Systems Development) created by Robert Branson, Gail Rayner, J. Lamar Cox, John P. Wallace H. Furman and Hannum (1975), includes the following steps:

- task analysis, prioritizing of exercise or training tasks, where the results are measurable;

- design of content and activities, which are studied and developed taking into account the proposed objectives, and including tests to verify the results considering these objectives;

- development, comprising the construction and testing of materials;

- implementation, which refers to this proper instruction and presents an improvement plan; and

- assessment, which can be of two types, internal, conducted with students, or external, based on the performance of graduates.

The ASSURE model (Heinich, Molenda, Russell \& Smaldino, 1999) includes the following steps:

- analysis of the characteristics of the students;

- definition of learning objectives;

- selection, modification or design of materials;

- use of materials;

- motivating students to get their answers; and

- evaluation.

In the next section some data models for the design of virtual courses and educational websites are presented, and the advantages and disadvantages of each are exposed.
- diseño y desarrollo de la evaluación formativa;

- diseño y desarrollo de la evaluación sumativa, que alude al valor de la instrucción; y

- revisión de la instrucción.

El modelo IPISD (Interservices Procedures for Instructional Systems Development) creado por Robert Branson, Gail Rayner, J. Lamar Cox, John P. Furman y Wallace H. Hannum (1975), comprende las siguientes fases:

- análisis de tareas, dando prioridad a las de ejercitación o entrenamiento, cuyos resultados son medibles;

- diseño de contenidos y actividades, que se estudian y desarrollan para alcanzar los objetivos, e incluye pruebas para verificar los resultados obtenidos considerando los objetivos propuestos;

- desarrollo, que comprende la construcción y prueba de los materiales;

- implementación, que hace referencia a la instrucción propiamente dicha y presenta un plan de mejoramiento; y

- evaluación, la cual puede ser de dos tipos, interna, llevada a cabo con los estudiantes, o externa, realizada con base en el desempeño de los graduados.

El modelo ASSURE (Heinich, Molenda, Russell \& Smaldino, 1999) abarca los siguientes pasos:

- análisis de las características de los estudiantes;

- definición de los objetivos de aprendizaje;

- $\quad$ selección, modificación o diseño de los materiales;

- uso de los materiales;

- motivación a los estudiantes para obtener sus respuestas; $\mathrm{y}$

- evaluación.

En la siguiente sección se presentan algunos modelos de datos para el diseño de cursos virtuales y sitios web educativos, y se exponen las ventajas y desventajas de cada uno.

IV. Modelos de datos para el diseño de cursos virtuales y sitios web educativos, en el marco de los modelos instruccionales presentados

La mayoría de los modelos de datos elaborados en la fase de diseño de cursos virtuales dejan de lado algunos de los pasos o fases del diseño instruccional presentados en la sección anterior.

El modelo de datos propuesto por Quispe y Quispe (2011) fue creado como parte del desarrollo de un aula virtual para dar solución a problemas relacionados con: la publicación de la información, de tal forma que estuviera al alcance de estudiantes y docentes; la asignación de trabajos y tareas; la gestión de las calificaciones de actividades eva- 


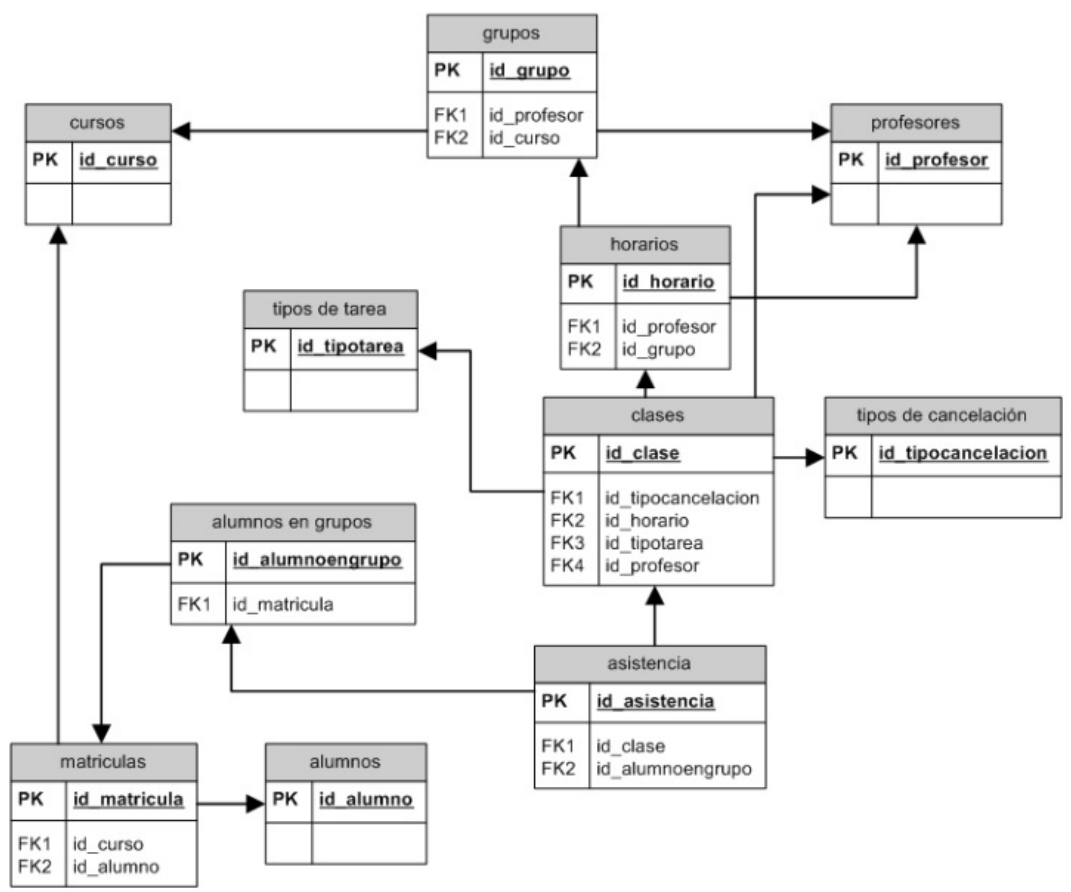

Figure 1. Data model proposed by Quispe and Quispe (2011) in the process of designing a virtual classroom / Modelo de datos propuesto por Quispe y Quispe (2011) en el proceso de diseño de un aula virtual

luativas; el apoyo del trabajo colaborativo y la interacción estudiante-docente, véase Figura 1.

Entre las desventajas de este diseño podemos enumerar las siguientes: no se visualiza un campo para especificar la meta instruccional de cada curso virtual ni el objetivo de aprendizaje de cada unidad de contenido al interior de un curso, la entidad alumno no incluye atributos que permitan registrar las conductas y características del estudiante y no existe una entidad para almacenar las calificaciones que los estudiantes obtienen al realizar las tareas calificables o actividades evaluativas.

Agudelo y Carmona (2012) proponen un modelo de datos en el proceso de diseño de un prototipo de sitio web educativo (Figura 2). El modelo incluye la definición de una entidad persona donde cada ocurrencia de dicha entidad puede ser una especialización de los subtipos administrativo, docente o alumno. La aplicación desarrollada a partir del modelo propuesto estará en capacidad de gestionar la información relacionada con: materias, grupos, asistencias e inasistencias y notas de los estudiantes.

Algunas desventajas del modelo propuesto son:

- los nombres de las relaciones no se especifican, lo que hace que el modelo no sea fácil de interpretar;

- en la definición de la entidad alumno solo aparecen como atributos propios el grado actual y la actividad del estudiante (si está activo o no), atributos que no serían suficientes para registrar las conductas y características del alumno, buscando una mejor orientación del mismo en su proceso de aprendizaje; y

\section{Data models for the design of virtual courses and educational websites, as part of the instruction- al models presented}

Most data models developed in the design phase of virtual courses leave out some of the steps or phases of instructional design presented in the previous section.

The data model proposed by Quispe and Quispe (2011) was created as part of the development of a virtual classroom to solve problems related to: the publication of information, to be available to students and teachers; assigning jobs and tasks; management qualification assessment activities; support for collaborative work and student-teacher interaction, see Figure 1.

Among the disadvantages of this design we can list the following: there is no field displayed to specify the instructional goal of each online course or the learning objective of each piece of content within a course, the student entity does not include attributes that can register student behaviors and characteristics, and there is no entity to store the grades that students get so as to perform qualifying tasks or assessment activities.

Agudelo and Carmona (2012) propose a data model in the design process of a prototype educational website (Figure 2). The model includes the definition of an individual entity where each occurrence of the entity can be a specialization of administrative subtypes, teacher or student. The application developed from the proposed model will be able to manage information related to: materials, groups, attendance and absences, and student grades.

Some disadvantages of the proposed model are:

- the names of relations are not specified, which means that the model is not easy to interpret;

- in the definition of the student entity, the only attributes that appear are the current level and student activity (active or not), attributes that are not sufficient to record the behavior and characteristics of a student, looking for a better orientation thereof in their learning process; and 


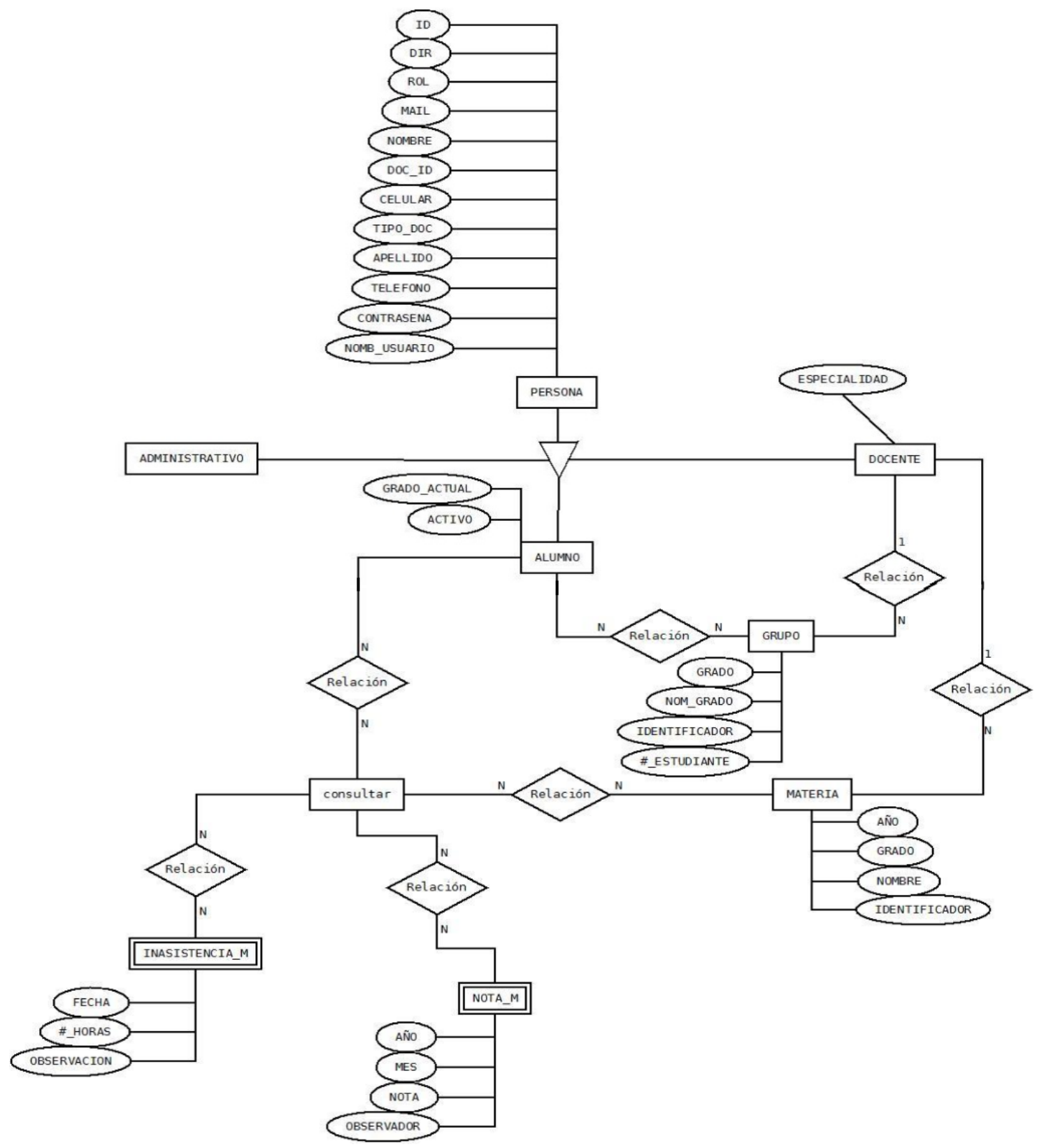

Figure 2. Data model proposed by Agudelo and Carmona (2012) in the design of an educational website / Modelo de datos propuesto por Agudelo y Carmona (2012) en el diseño de un sitio web educativo

- entities are needed to store content units with their learning objectives and learning and evaluative activities.

\section{Data model that includes in- structional design guidelines in vir- tual course modeling}

The proposed model (FIGURE 3) describes the entities, attributes and relationships that are relevant in the design of virtual courses. The immersed semantics in the proposed model is as follows:
- hacen falta entidades para almacenar las unidades de contenido con sus objetivos de aprendizaje y las actividades de aprendizaje y evaluativas.

V. Modelo de datos que incluye lineamientos del diseño instruccional en el modelado de curso virtual

El modelo propuesto (Figura 3) describe las entidades, atributos y relaciones relevantes en el diseño de cursos virtuales. La semántica inmersa en el modelo propuesto es la siguiente: 

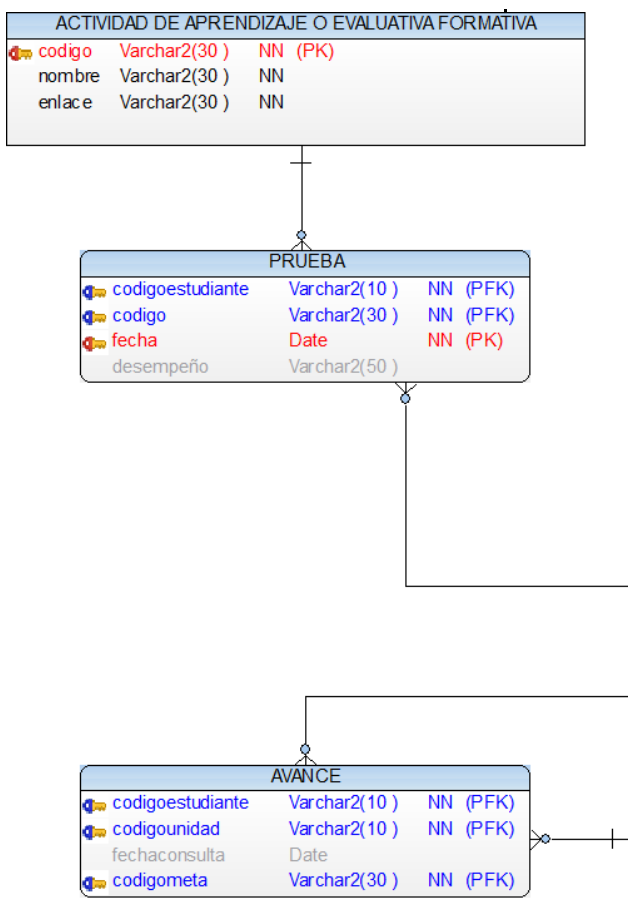

TAREA OACTIVIDAD EVALUATIVA SUMATIVA

Am codigotarea Varchar2(10) NN (PK)

nombre $\quad$ Varchar2(30) NN

enlace $\quad \operatorname{Varchar} 2(30) \quad \mathrm{NN}$

porcentaje Number
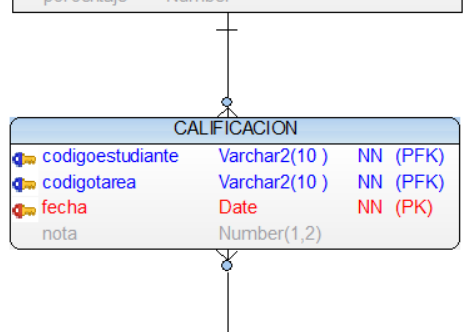
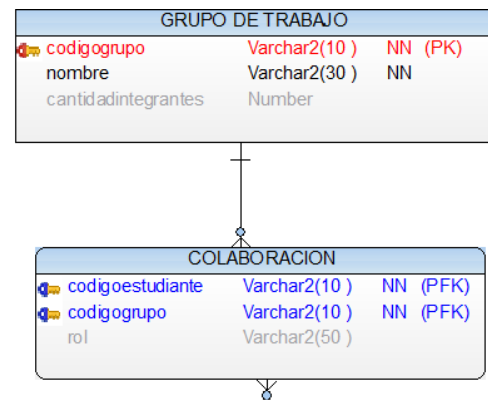

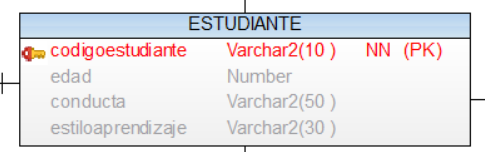

$+$

\begin{tabular}{|c|c|c|c|c|c|c|}
\hline \multicolumn{3}{|c|}{ UNIDAD DE CONTENIDO } & & \multicolumn{3}{|c|}{ MATERIAL DE INSTRUCCION } \\
\hline codigounidad & $\operatorname{Varchar2(10)}$ & NN (PK) & & q $\approx$ codigomaterial & Varchar2(10) & NN (PK) \\
\hline nombre & Varchar2(30) & (AK1) & & a nombre & Varchar2(30) & NN (PFK) \\
\hline objetivo & Varchar2(50) & & & enlace & Varchar2(30) & NN \\
\hline enlace & $\operatorname{Varchar} 2(30)$ & & & tipo & $\operatorname{Varchar} 2(30)$ & \\
\hline codigometa & $\operatorname{Varchar} 2(30)$ & NN (PFK) & & formato & Varchar2 $(30)$ & \\
\hline
\end{tabular}

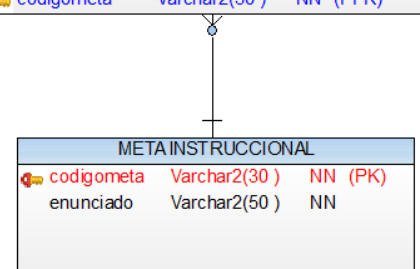
$\operatorname{Varchar} 2(30)$

Figure 3. Data model for designing virtual courses including instructional design guidelines /

Modelo de datos para el diseño de cursos virtuales incluyendo lineamientos del diseño instruccional

El modelo incluye entidades y atributos que permiten la definición de una meta instruccional para el curso virtual a diseñar, además, la entidad Unidad de Contenido, en su atributo Objetivo, permite plantear la meta de cada unidad.

Este modelo incorpora la definición de la entidad Estudiante, cuyos atributos permiten registrar, no solo la información general, sino también las conductas y estilos de aprendizaje de los estudiantes, información que le facilita al docente o tutor la tarea de orientar el proceso de aprendizaje.

La entidad Material de Instrucción permitirá almacenar cualquier material educativo virtual sin importar su tipo (texto, audio, video, imagen, etc.). Estos materiales se emplearán en la construcción de las unidades de contenido, según se indique la estrategia instruccional. La entidad Estrategia Instruccional no se ve reflejada en el modelo puesto que es una tarea que precede al desarrollo del curso virtual y que no es de interés del estudiante, sólo del docente o tutor. La estrategia instruccional se apreciaría entonces en el diseño de: las unidades de contenido, las actividades de aprendizaje, las actividades evaluativas, las colaboraciones en los grupos de trabajo, los materiales de instrucción y las relaciones que existan entre las entidades anteriores para dar cumplimiento a los objetivos propuestos.
The model includes entities and attributes that allow the definition of an instructional goal for the virtual course to be designed. Also, the entity Unidad de Contenido in the Objetivo attribute allows the target of each unit to be set.

This model incorporates the definition of the Estudiante entity, whose attributes make it possible to register not only general information but also the behaviors and learning styles of students, information that facilitates the teacher or tutor in the task of guiding the learning process.

The entity Material de instrucción will make it possible to store any virtual educational material regardless of type (text, audio, video, image, etc.). These materials are used in the construction of the content units, according to the instructional strategy indicated. The Estrategia Instruccional entity is not reflected in the model since it is a task that precedes the development of the virtual course and is not of interest to the student, only to the teacher or tutor. The instructional strategy will then appreciate the design of the content units, learning activities, the evaluation activities, collaboration in working groups, instructional ma- 
terials and the relationships that exist between the above entities to comply with the proposed objectives.

The Tarea o Actividad Evaluativa Sumativa entity needs to be assessed by a rating. On the other hand, if the evaluation is formative or is a learning activity, its intention will be the consolidation of the content units and it will not need to be assigned a rating. Among the tasks or those formative evaluation activities will be oriented exercise, practice or training (widely used instructional strategies based on pedagogical approaches to behavior). The model does not include an entity or attributes for external evaluation, because the designed online courses using this model will just allow the evaluation of students, not the evaluation of graduates.

Instruction Revision is a task that is performed after the design and implementation of the virtual course, and for this reason will not be reflected in the model. This review may lead to changes in an already defined instructional strategy.

After specifying the steps or phases of the instructional design models that will be reflected in the proposed model, the entities, attributes and relationships that describe the elements involved in the design of a virtual course are presented.

This model, unlike those discussed in the previous section, makes it possible to:

- specify the virtual course's instructional goal and the purpose of each content unit;

- record the characteristics, learning styles and behaviors of the student;

- store the content, assessment tools and materials to guide learning;

- monitor the content consulted by students; and

- record the notes of each student in different tasks or evaluation activities and collect information related to collaboration among students when performing group work.

A data model as proposed in this article enables the evaluation to be clear about what should be measured, personalizing the learning process and analyzing how it progresses, works and relates to each student.

\section{Conclusions and future work}

From a critical review of three instructional models and two data models, this article proposes a data model that includes instructional design guidelines for modeling virtual
La entidad Tarea o Actividad Evaluativa Sumativa requiere ser valorada mediante una calificación. Por otra parte, si la evaluación es formativa o se trata de una actividad de aprendizaje, su intensión será el afianzamiento de las unidades de contenidos y no será necesario asignar una calificación. Entre las tareas o actividades evaluativas formativas estarán aquellas orientadas a la ejercitación, práctica o entrenamiento (muy usadas estrategias instruccionales basadas en enfoques pedagógicos conductistas). El modelo no incluye una entidad, ni atributos para la evaluación externa, dado que los cursos virtuales diseñados a partir de este modelo solo permitirán la evaluación de estudiantes, no la de egresados o graduados.

La revisión de la instrucción es una tarea que se realiza después del diseño e implantación del curso virtual, por esta razón no se verá reflejada en el modelo. Esta revisión puede generar cambios en una estrategia instruccional ya definida.

Una vez especificados los pasos o fases de los modelos de diseño instruccional que se verán reflejados en el modelo propuesto, se presentan las entidades, los atributos y las relaciones que describen los elementos que intervienen en el diseño de un curso virtual.

Este modelo, a diferencia de los analizados en la sección anterior, permite:

- especificar la meta instruccional del curso virtual y el objetivo de cada unidad de contenido;

- registrar las características, los estilos de aprendizaje y las conductas del estudiante;

- almacenar los contenidos, instrumentos para la evaluación y materiales para orientar el aprendizaje;

- realizar seguimiento a los contenidos consultados por los estudiantes; y

- registrar las notas de cada estudiante en las diferentes tareas o actividades evaluativas y recopilar la información relacionada con las colaboraciones entre los estudiantes para realizar un trabajo de grupo.

Un modelo de datos como el propuesto en este artículo facilita la evaluación al tener claro lo que se debe medir, la personalización del proceso de aprendizaje y el análisis de la forma en la que avanza, se desempeña y relaciona cada estudiante.

\section{Conclusiones y trabajo futuro}

A partir de la revisión crítica de tres modelos instruccionales y dos modelos de datos, en este artículo se propone un modelo de datos que incluye lineamientos del diseño instruccional para el modelado de cursos virtuales. A partir de las fases, pasos o actividades de diferentes modelos instruccionales se identificaron las entidades, los atributos y las relaciones que describen la estructura de un curso virtual.

Otros modelos de datos para el diseño de cursos virtuales o de sitios web educativos no consideran los lineamientos 
del diseño instruccional; entre las carencias más comunes están: la falta o incompletitud en la definición de la entidad estudiante, que no permite registrar sus conductas y características relacionadas con el proceso de aprendizaje; la inexistencia de atributos para guardar la meta instruccional del curso virtual; y la ausencia de campos para almacenar los objetivos de aprendizaje de cada unidad de contenido. Las carencias anteriores dan cuenta de la definición de una estrategia instruccional incompleta que probablemente no llevará a un buen proceso de aprendizaje.

El modelo propuesto incluye elementos representados por medio de entidades y atributos y además establece relaciones entre tales elementos, identificados a partir del estudio de diferentes modelos de diseño instruccional, por lo que constituye un aporte a la formalización del proceso de diseño instruccional de cursos virtuales. Por esta razón, se plantea, como trabajo futuro, la definición de un metamodelo o de una ontología a partir de los cuales se puedan construir nuevos modelos no solo para el diseño de cursos virtuales sino también para el diseño de otro tipo de aplicaciones de software educativo. $\$$ T courses. From the phases, steps or activities of the different instructional models, entities, attributes and relationships that describe the structure of a virtual course were identified.

Other data models for the design of virtual courses or educational websites do not consider the guidelines for instructional design. Among the most common deficiencies are: the lack or incompleteness in the definition of the student entity, which does not allow the registration of their behaviors and characteristics related to the learning process; the absence of attributes to save the instructional goal of the virtual course; and the absence of fields to store the learning objectives of each content unit. The above shortcomings amount to the definition of an incomplete instructional strategy that will probably not be a good learning process.

The proposed model includes elements represented by entities and attributes and establishes relationships between such elements identified from the study of different instructional design models, so it is a contribution to the formalization of the process of the instructional design of online courses. For this reason, it is proposed in future work to define a metamodel or ontology from which to build new models not only for the design of virtual courses but also for the design of other educational software applications. S\&

\section{References / Referencias}

Agudelo, D. \& Carmona, L. (2012). Prototipo web educativo [trabajo de grado]. Universidad Católica de Pereira: Colombia.

Branson, R., Rayner, G. Cox, J.L., Furman, J.P., Hannum, W.H.. (1975). Interservices Procedures for Instructional Systems Development [report to US Army Combat Arms Training Board ADA 019 486]. Retrieved from: http://www.dtic.mil/dtic/tr/ fulltext/u2/a019486.pdf

Dick, W., Carey, L., \& Carey, J.O. (2005). The systematic design of instruction [6a. ed.]. New York, NY: Allyn \& Bacon.

Heinich, S., Molenda, J., Russel, R., \& Smaldino, M. (1999). The ASSURE model: instructional media and technologies for learning. Upper Saddle River, NJ: Pearson.

Miller, S. M. \& Miller, K. L. (2000). Theoretical and practical considerations in the design of Web-based instruction. In: B. Abbey (Ed.), Instructional and cognitive impacts of web-based education. Hershey, PA: Idea Group Publishing.

Ministerio de Educación Nacional [MEN]. (2011). Orientaciones para el diseño, producción e implementación de cursos virtuales [working paper]. Bogotá DC, Colombia: MEN.

Quispe, L. \& Quispe, R. (2011). Proyecto de sistema "aula virtual” [trabajo de grado]. Instituto Continental: Huancayo, Perú.

Reigeluth, C.M. (1983). Instructional design: what is it and why is it? In C.M. Reigeluth (Ed.), Instructional design theories an models: an overview of their current status. Hillsdale, NJ: Eribaum.

Saettler, P. (2004). The evolution of American educational technology. Charlotte, NC: Information Age Publishing.

Vidal, M., Gómez, F., \& Ruiz, A. (2010). Software educativo. Educación Médica Superior, 24(1), 97-110. 
CURRICULUM VITAE

Betsy Mary Estrada Perea Candidate in Systems Engineering from the Universidad Nacional, in Medellin; Master in Systems Engineering, Systems Engineering and Computer Science; full-time teacher and researcher at the Faculty of Engineering at the Institución Universitaria de Envigado / Candidata a Doctora en Ingeniería de Sistemas de la Universidad Nacional, sede Medellín; Magister en Ingeniería de Sistemas; Ingeniera de Sistemas e Informática; docente de tiempo completo e investigadora de la Facultad de Ingenierías de la Institución Universitaria de Envigado. 